\title{
Homeowners of Beijing, Unite! The construction of a collective mobilisation
}

\section{Aurore Merle}

Translator. Will Thornely

\section{OpenEdition Journals}

\section{Electronic version}

URL: http://journals.openedition.org/chinaperspectives/6441

DOI: 10.4000/chinaperspectives.6441

ISSN: 1996-4617

\section{Publisher}

Centre d'étude français sur la Chine contemporaine

\section{Printed version}

Date of publication: 1 June 2014

Number of pages: 7-15

ISSN: 2070-3449

\section{Electronic reference}

Aurore Merle, "Homeowners of Beijing, Unite! The construction of a collective mobilisation », China Perspectives [Online], 2014/2 | 2014, Online since 01 January 2017, connection on 28 October 2019 URL : http://journals.openedition.org/chinaperspectives/6441 ; DOI : 10.4000/chinaperspectives.6441 


\title{
Homeowners of Beijing, Unite!
}

\section{The construction of a collective}

\section{mobilisation}

\author{
AURORE MERLE
}

\begin{abstract}
The move towards access to private homeownership represents a "revolution" in urban China during the reform era. New private residences not only symbolise "modernity"; they also set the scene for conflicts that pit homeowners, property developers, residents' committees, and local authorities against one another. By studying the attempt to form a "federation" of homeowners' committees in the city of Beijing, this article recounts and analyses the steps taken to construct a collective mobilisation, which involved the formation, in 2006, of an "application committee" requesting the creation of a federation of Beijing homeowners, the national petition launched in 2007 at the time of the debate on the Property Law (Wuquan fa), the organisation of "training classes" for homeowners in 2009, and the process of developing a new local regulation in Beijing in 2010.
\end{abstract}

KEYWORDS: private homeownership, homeowners' committees, collective mobilisations, protection of rights (weiquan).

\section{Introduction}

A the beginning of 2007, shortly before the Property Law (Wuquan fa 物权法) was to be adopted by the National People's Congress, a citizens' petition brought the voice of homeowners to the forefront. Attracting more than 180,000 signatures, it called for certain articles of the law to be revisited in the name of the rights and interests of homeowners. In a highly symbolic move at the beginning of 2010, more than 200 homeowners from Chinese cities came together at the National People's Congress as part of the official launch of a "platform" aiming to coordinate the various actors in "neighbourhood communities." (1) These two events illustrate the appearance of a new "social figure": the homeowner (yezhu 业主), linked to housing reform taking place in urban China since the mid-1990s. They also reflect the extent to which the deep spatial and social reconfigurations affecting Chinese cities since the mid-1990s and, in particular, during the 2000s, have given rise to many channels through which contestations and calls for recognition linked to the question of housing are expressed. These include protests against the destruction of entire neighbourhoods and the brutal expulsion and relocation imposed on their inhabitants, mobilisations in new residences to defend the rights of homeowners against property developers and the local authorities, and finally collective actions in order to win recognition in the newly created "neighbourhood communities" of new "intermediate actors": homeowners' committees (yezhu weiyuanhui 业主 委员会). Above all, their national and symbolic dimension shows that although conflicts concerning housing are often local affairs that are tied in with a specific situation, some actors attempt to reach beyond these territorial boundaries to unify different interests and claims.

By studying the attempt to form a "federation" of homeowners' committees in the city of Beijing, this article recounts and analyses the various steps taken to construct a collective mobilisation. Why and how have homeowners living in different neighbourhoods of Beijing joined forces? ${ }^{2}$ (2) How have they constructed and drawn up collective claims based on the definition of a common interest? What strategies have they developed to mobilise and encourage other homeowners to join their movement? Finally, in an uncertain context in which any attempt to form an association may be considered suspicious by representatives of the one-party state, (3) how have they drafted their demands to the authorities in order to make them acceptable without neutralising their impact?

Founded in 2006 by several homeowners' committee leaders, the yeshenwei (业申委) - shortened from Beijing shi yezhu weiyuanhui xiehui de shenban weiyuanhui (北京市业主委员会协会的申办委员会) or "Application committee requesting authorisation for a federation of the homeowners' committees of Beijing" in English - is seeking, as its name suggests, to obtain the official creation and recognition of a new body to represent homeowners at the municipal level. This is a relatively rare experiment in China, because as far as we are aware, only one other equivalent asso-

1. Observation notes, 20 January 2010.

2. Isabelle Thireau (ed), De proche en proche. Ethnographie des formes d'association en Chine contemporaine (Face-to Face:An Ethnography of Forms of Association in Contemporary China), Bern, Peter Lang, 2013. See the introduction (pp. 11-21) and the article "Agir ensemble à Dongcun, ou le surgissement caché du politique" (Working together in Dongcun, or the concealed appearance of politics) (pp. 153-194), by Isabelle Thireau. This work approaches associations in China from the perspective of actual processes of cooperation and association of individuals, repertoires and mechanisms of action that have been mobilised, and "ethical, legal and political figures used [...] to redefine modes of cooperation." The question of politics appears to be essential, owing to the extent to which relations with the public authorities restrict the scope for action, and these relations appear to be "highly contrasting, full of dissymmetry and reciprocity, cooperation and manipulation, acquiescence and repression."

3. Ching Kwan Lee and Yonghong Zhang, "The Power of Instability: Unraveling the Microfoundations of Bargained Authoritarianism in China," American Journal of Sociology, Vol. 118, No. 6, May 2013, pp. 1475-1508 
ciation has been formed, in Guangzhou. (4) This movement-organisation is not only aiming to win official recognition, but will also attempt to develop its legitimacy and strengthen its capacities through a certain number of actions that need to be described for a better understanding of the stakes involved. A number of events or "collective action situations" (5) will therefore be looked at, including the creation of this "application committee" in 2006, the petition to revise the Property Law launched in 2007, the organisation of "training classes" (peixunban 培训 班) for homeowners in 2009, and the process of drawing up new local regulations in Beijing in 2010.

This sociological investigation was carried out as part of a post-doctoral study completed in the Sociology Department of Tsinghua University in 2009-2010 within the research team directed by Mrs. Guo Yuhua and Mr. Shen Yuan, ${ }^{(6)}$ who have, since 2006, been following the shocks, high points, and problems encountered by this collective action by Beijing homeowners as part of their research into "urban movements" (dushi yundong 都市运动). Taking inspiration from Alain Touraine's sociological intervention method, (7) the sociologists have been able to get as close as possible to the nascent movement, sometimes welcoming its participants to the university for the purpose of organising meetings, and attending certain events in person. It is this specific position, at once engaged and engaging, that allows them to grasp, in fine detail, all the constraints and contradictions faced by those who are attempting to establish such collective action. ${ }^{(8)}$ In June 2009, when I joined the group, certain founding events had already taken place, and others less visible were underway. As a post-doctoral student working in the research team, and sometimes working as a volunteer in the organisation of certain events, I was able to observe many meetings. Collective interviews were carried out with different actors in order to gain an understanding of the latest developments of the movement, and individual interviews were conducted with certain leaders, in particular founding members of the "application committee." Finally, a considerable collection of documents for internal usage was also gathered.

Before describing this collective mobilisation, it is helpful to first reconsider the "revolution" that housing reform in urban China represents, and the particular attention to which it gave rise.

\section{Housing reform in urban China: A "revolution"}

Since the 1990s, Chinese cities have experienced a "housing revolution" in which the model by which housing was distributed by the work units (danwei fenfang 单位分房), a feature of the planned economy, has been replaced by a new market system in which each individual purchases his own home (geren maifang 个人买房). ${ }^{(9)}$ The formation of a housing market and the move towards access to homeownership in the upper and middle classes of urban society not only completely changed the morphology of cities but also profoundly modified the structure of urban society, ${ }^{(10)}$ creating a new social figure, the homeowner (yezhu), as well as a new organisation, the "homeowners' committee," which was responsible for managing the new residential spaces.

Owning one's own home became a fundamental issue for citizens, because it provided access to a new position of material comfort, indicating a certain level of status or social success, and embodying the promise or achievement of matrimonial and family plans. However, far from being the peaceful havens that had been envisaged, the "neighbourhood communi- ties" (shequ 社区) turned into battlefields where the relations between different categories of actors were brought into play: ${ }^{(11)}$ owners grouped together into movements to defend their rights (weiquan 维权) or into "homeowners' committees" (yezhu weiyuanhui or, in the shortened form, yeweihui), property developers and affiliated management companies or managing agents (wuye gongsi 物业公司), and finally, residents' committees ${ }^{(12)}$ (jumin weiyuanhui 居民委员会 or, in the shortened form, juweihui), which despite supposedly representing the residents, actually represented the most local level of political power. ${ }^{(13)}$

This transformation of Chinese cities (and the social struggles it has triggered) has not only attracted the attention of the government, the population as a whole, and the media, but has also become a "field of interdisciplinary research including sociology, political science, law, and public management." (14) The central question facing researchers and actors relates to the reconfiguration of the links and power relations between "state,"

4. Zhang Jingen and Zhuang Wenjia, "Fei zhengshi zhengzhi: yige caogen NGO de xingdong celüe Yi Guangzhou yezhu weiyuanhui lianyihui choubei weiyuanhui wei li" (Informal politics:The tactics of action of a grassroots NCO - The example of the preparation committee for the association of homeowners' committees in Guangzhou), Shehuixue yanjiu (Sociological studies), No. 2, 2008; Ngai-ming Yip and Yihong Jiang, "Homeowners United:The attempt to create lateral networks of homeowners' associations in urban China," Journal of Contemporary China, Vol. 20, No. 72, 2011, pp. $735-750$.

5. Daniel Cefaï, Pourquoi se mobilise-t-on ? Les théories de l'action collective (Why do we mobilise? Theories of collective action), Paris, La découverte/Mauss, 2007, in particular the chapter "Analyse de situations d'action collective" (Analysis of collective action situations), pp. 626-701.

6. I would like to express my sincere gratitude to Professors Guo Yuhua and Shen Yuan and to the other members of the team: Jin Jun, Liu Zixi, Liu Yuewen, Chen Peng, and Bi Xiangyang.

7. See Alain Touraine, Le retour de l'acteur (The Return of the Actor), Paris, Fayard, 1984, pp. 197217; Shen Yuan, "'Intervention forte' et 'intervention faible': deux voies d'intervention sociologique" ('Strong intervention' and 'weak intervention': Two approaches of sociological intervention method), Cahiers internationaux de sociologie, No. 122, June 2007, pp. 73-104.

8. See Guo Yuhua and Shen Yuan, "Juzhu de zhengzhi - B shi yezhu weiquan yu shequ jianshe de shizheng yanjiu" (Housing Politics: Empirical research on the rights' defence of homeowners and the building of urban communities in B City), Kaifang shidai, No. 2, 2012, www.opentimes.cn/bencandy.php?fid=331\&aid=1573 (accessed on 14 March 2014).

9. See the work of Youqin Huang: "The Road to Homeownership: A Longitudinal Analysis of Tenure Transition in Urban China (1949-1994)," International Journal of Urban and Regional Research, Vol. 28, No. 4, 2004, pp. 774-95; "From Work-unit Compounds to Gated Communities: Housing Inequality and Residential Segregation in Transitional Beijing," in Laurence J. C. Ma and Fulong Wu, Restructuring the Chinese Cities: Changing Society, Economy and Space, London/New York, Routledge, 2005, pp. 192-221; Youqin Huang and Siming Li, "Housing Inequality, Residential Differentiation, and Socio-spatial Stratification: Chinese Cities in the Early 21st Century," in Youqin Huang and Siming Li, Housing Inequality in Chinese Cities, London/New York, Routledge, 2013, Chapter 1. See also You-tien Hsing, The Great Urban Transformation: Politics of Land and Property in China, Oxford, Oxford University Press, 2010.

10. Luigi Tomba, "Making Neighbourhoods: The Government of Social Change in China's Cities," China Perspectives, No. 2008/4, pp. 48-62

11. Li Zhang, In Search of Paradise: Middle-Class Living in a Chinese Metropolis, Ithaca, Cornell University Press, 2010.

12. Judith Audin, "Le quartier, lieu de réinvention des relations État-société en Chine urbaine: l'exemple des comités de résidents à Pékin" (The neighbourhood, the place where State-Society relations are reinvented in urban China:The example of residents' committees in Beijing), Raisons politiques, No. 29, 2008, pp. 107-117, and Vie quotidienne et pouvoir dans trois quartiers de Pékin. Une microsociologie politique comparée des modes de gouvernement urbain au début du 21ème siècle (Power and daily life in three urban neighbourhoods in Beijing: A comparative political microsociology of urban government at the beginning of the 21st century), Paris Institute of Political Sciences, 6 February 2013; Wang Di, "Operating Norms and Practices of Residents' Committees: The consequences and limits of management by numbers," China Perspectives, No. 2013/1, pp. 7-16.

13. Conflicts between homeowners and property developers often relate to problems concerning the housing (actual surface area, quality of the construction, changes to use plans of the residence, new constructions, etc.), the ownership and use of the communal spaces (car parks, clubs and conference spaces, green spaces, etc.), the various maintenance costs of the residence (fees owed to the management company, electricity, water and heating bills, the renovation fund of the residence, etc.), and the choice of management company and its replacement (quality of services, private security company, etc.). See below for conflicts between homeowners and residents' committees.

14. Chen Peng, "Cong 'chanquan' zouxiang 'gongminquan' - Dangqian Zhongguo chengshi yezhu weiquan yanjiu" (From "property rights" to "citizens' rights": A study on the defence of homeowners' rights in contemporary urban China), Kaifang shidai, 2009, No. 4. 
"market," and "society" in these new residential spaces: how is a new order being constructed in these emerging communities? On the one hand, attention is drawn to the "movement," i.e., collective actions by middle-class citizens to defend their rights (weiquan yundong), the forms such actions take, the resources they mobilise and the interests that they represent. ${ }^{(15)}$ On the other hand, interest focuses on the "organisation" of these new residential spaces made completely from scratch into the gated communities described by Luigi Tomba, and on their modes of governance. Homeowners' committees attract particular attention. These new "intermediate bodies" are legally recognised but controversial, and their election procedures, operating mechanisms, and scope of competence are the subject of many conflicts, including of a political nature. Which forms of intervention are actually exercised by the one-party state through the residents' committees and various authorities (Sub-district Offices, Ministry of Civil Affairs, Construction Bureaus, etc.), and what degree of independence do these new representative bodies enjoy?

The answers to these questions reveal many different realities. Therefore, whereas the sociologist Shen Yuan, citing the city of Beijing as an example, shows how these new "urban movements" are contributing to the emergence of a discourse and claims centred around citizenship and show a certain degree of independence enjoyed by homeowners relative to the existing administrative bodies, (16) his Shanghai colleague, Chen Yingfang, underlines the severe constraints weighing on these movements and their actors and the heavy influence of the one-party state. ${ }^{(17)}$ Luigi Tomba establishes a link between the emergence of protest actions by homeowners and the closing of residential spaces but also shows that the privatisation of a section of the services owned by the state goes hand in hand with the adherence and loyalty of these middle-class citizens towards the state. ${ }^{(18)}$ Finally, Benjamin Read emphasises the extreme variability of the situations that characterise homeowners' associations, depending not only on the location in question, but also on changes over time, and the intensity of the conflicts. ${ }^{(19)}$ This complexity is deepened by the deep-rooted nature of local configurations, and regulations and practices that vary depending on the city, district, and neighbourhood.

In this article, we have chosen to set out the courses of action carried out by the yeshenwei or "application committee" in Beijing since 2006. This involves observing not the residential neighbourhood (小区) but a collective action aiming to bring together various local contesting claims and regroup the different actors mobilised to defend the rights of homeowners within a "federation" (xiehui). By shifting the focus and the level of the analysis, this approach makes it possible to show how actors faced with this diverse range of situations and commitments are able (or not) to define common problems, to join forces around shared objectives, and to construct collective claims. Studying the project to apply to form a "federation" draws attention to the events that triggered this action, the individuals central to this approach, and the forms used to explain this application to the homeowners in question and to the authorities. Analysing the initiative of an open letter shows how a collective claim aiming to affect the drawing up of laws is constructed. Finally, observing the training classes for homeowners and the interactions between the yeshenwei and certain authorities, it was possible to see how the space for action formed by the yeshenwei is not limited to formulating claims but also aims to produce, share, and encourage homeowners and the local authorities to adopt practices of cooperation, and norms and rules of operation for homeowner associations.

\section{The birth of the yeshenwei: The formation of a new "intermediate body" in Beijing}

At the start of the 2000s, conflicts within newly constructed commodity residences (shangpin fang 商品房) were increasing inexorably. In Beijing, the movement to defend the rights of homeowners reached its peak in 20052006, when not only did the number of cases submitted to the courts concerning disputes with management companies (wuye gongsi) increase sharply, but collective complaints by homeowners and street protests also became a relatively common phenomenon. ${ }^{(20)}$ Although the practices of management companies are often the triggering factor in a collective action taken by homeowners, during the course of the struggle it is the very possibility of forming a "homeowners' committee" that gradually grows to become the main undertaking of the movement. According to certain statistics, of the approximately 3,000 residences in the city of Beijing in 2007 , only 500 had created a homeowners' committee in accordance with the regulations, which is a percentage of less than $20 \%$. (21) Despite the fact that, since 2003, a regulation issued by the State Affairs Council has set out the rules and steps for forming this new representative body, ${ }^{(22)}$ in practice, homeowners are faced with a whole series of obstacles from residents' committees and the various local authorities.

The birth of the yeshenwei is the result of two events that took place in this context. The first was the opportunity offered to homeowners by the "market" to meet or, in other words, the possibility of forming horizontal relations between the various actors of the movements. As noted by Liu Yuewen, (23) the founders of the yeshenwei actually met as a result of a meeting organised by a bank, which invited all the presidents of the homeowners' committees of the city of Beijing to a promotional semi-

15. For example, see the research undertaken by Cai Yongshun on the forms of protest of the urban middle classes in China: "China's moderate middle class: The case of homeowners' resistance," Asian Survey, No. 5, 2005, pp. 777-799; "Civil Resistance and rule of law in China: The case of defending homeowners' rights," in Elizabeth Perry and Merle Goldman (eds), Grassroots Politics in China, Cambridge, Harvard University Press, pp. 174-195

16. Shen Yuan, "Vers les droits du citoyen: la défense des droits des propriétaires comme mouvement citoyen dans la Chine contemporaine" (Towards the rights of the citizen: The defence of homeowners' rights as a citizen movement in contemporary China), in Laurence Roulleau-Berger, Guo Yuhua, Li Peilin, and Liu Shiding (eds), La nouvelle sociologie chinoise (New Chinese Sociology), Paris, Éditions du CNRS, 2008, pp. 299-326.

17. Chen Yingfang, "Les mouvements de protestation des classes moyennes" (Middle-class protest movements), in Jean-Louis Rocca (ed), La société chinoise vue par ses sociologues (Chinese society seen by sociologists), Paris, Presses de Sciences Po, 2008.

18. Luigi Tomba, "Residential space and collective interest formation in Beijing's housing disputes," China Quarterly, No. 184, 2005, pp. 934-951; "Making Neighbourhoods: The Government of Social Change in China's Cities," art. cit.

19. Benjamin Read, "Democratizing the neighbourhood? New private housing and homeowner selforganization in urban China," The China Journal, No. 49, January 2003, pp. 31-59; "Assessing variations in civil society organizations: China's homeowner associations in comparative perspective," Comparative Political Studies, Vol. 41, No. 9, September 2008, pp. 1240-1265; Roots of the State: Neighbourhood Organization and Social Networks in Beijing and Taipei, Stanford, Stanford University Press, 2012.

20. Research team on urban movements, Beijing shi shangpin fang zhuzhai xiaoqu guanli moshi yanjiu baogao (Research report into management models of private residential communities in the city of Beijing), April 2010; Wuye guanli jiufen renmin diaojie lilun yu shiwu (Theory and facts concerning popular mediation of disputes with management companies), Beijing, Renmin wujing chubanshe, 2008.

21. See the 2008 report of the Consultative Conference Congress. "Guanyu Beijing shequ yezhu jingji zizhi zuzhi cunzai wenti zhidu he zhidu chuangxin de jianyi" (Concerning the institutional problems that exist with regard to organisations of economic self-management of the homeowners in Beijing residences and some advice concerning institutional innovation).

22. State Affairs Council, "Wuye guanli tiaoli" (Decree on the management of property), 8 June 2003.

23. See Liu Yuewen, Shehui de shanbian: yi B shi yi ge yezhu lianhe zuzhi weili (The transformation of society: The case of an organisation bringing the homeowners of the city of B. into contact), Masters dissertation, Sociology Department, Tsinghua University, June 2010. 
nar. (24) However, it was the emotion aroused by a violent incident that took place in April 2006 that convinced the actors in the movement to defend the rights of homeowners to transform this network of acquaintances into an organisation. During preparations for the creation of a homeowners' committee, two residents handing out ballot papers were violently beaten and injured by thugs working for the head of the security guards of the company managing the residence. ${ }^{(25)}$

Three individuals were responsible for the creation of this organisation linking various residences in the city of Beijing: Lao Z., Lao Q., and Xiao C., who would later be joined by Xiao R. (26) At the time, they were all presidents of the homeowners' committees of their residences, and had carried out actions in defence of their rights. For example, the residence where Lao Q. lived was one of the first in Beijing to have formed a homeowners' committee and to have succeeded in changing the management company. Xiao R. carried out a hunger strike in protest against the property developer of his residence. Whether engaged in contesting or conciliating actions, these four leaders possess a high level of symbolic capital within the movement to defend the rights of homeowners in the city of Beijing. Their biographies show the different trajectories they have taken. ${ }^{(27)}$

Born in the 1950s, Lao Z. and Lao Q. were deeply affected by the Cultural Revolution, whereas Xiao C. and Xiao R., who were born at the turn of the 1970s, were more influenced by the period of reform and opening up and by the 1989 student movement. Lao Z. came from a family of landlords, which meant they belonged to one of the "five black categories" identified by the Cultural Revolution, while Lao Q. came from a working class family, and the parents of Xiao $\mathrm{C}$. were both university professors. In terms of their education, it is worth noting that the four founders all went to university, Xiao C. and Xiao R. having studied at Peking University.

The professional lives of the four founders show a certain amount of success. After the launch of the policy of reform and opening up, Lao Z. entered the world of business, creating a company in the field of culture; he now owns several companies. Having graduated in economics and working in government institutions for a number of years, Lao Q. also entered the business world. Xiao C. worked in various companies involved in advertising and the media. Xiao R. came from Zhejiang, and on completion of his studies remained in Beijing to work. Finally, it should also be emphasised that Lao Z. is a member of the People's Political Consultative Conference of Beijing and that Lao Q. has been a member of the Minzhu jianguo hui (China National Democratic Construction Association) since 2008.

These biographical trajectories, in particular the different forms of capital held by the four actors (symbolic capital in terms of the defence of the rights of homeowners, cultural and economic capital, and political capital for some), play a role in the capacities in which this new organisation is able to act by enabling the yeshenwei to mobilise resources in various fields and draw on support from different social networks, some of which are within the system (tizhi nei) and others on the outside (tizhi wai). In terms of engagement and action strategies, although the four founders share the same general point of view, their different strategies and expectations can be seen on a daily basis in the details of how they organise collective action. For example, Lao Z. has the greatest tendency towards conciliation and indeed cooperation with the government and administrative authorities (City Construction Bureau, Bureau of Civil Affairs, etc.), while Lao Q. is more geared towards the "market" or the economy, having even set up a management company with another activist. By way of contrast, Xiao C. and Xiao R. hope rather to maintain the independence of the yeshenwei and to contribute to the construction of Chinese "civil society" (gongmin shehui). As the "theorist" of the four founders, Xiao $\mathrm{C}$. is a frequent contributor to discussions on online homeowner forums, setting out the principles that he believes should inspire the movement to defend the rights of homeowners and encourage the self-management of residential communities. Finally, Xiao R., who is the youngest of the founders, is the "organiser," responsible for concrete actions such as training classes for homeowners and meetings organised by the yeshenwei to discuss regulation projects.

In real terms, the process of forming the yeshenwei began in May 2006 with the organisation of a discussion platform at a residential community in Beijing. Bringing together around 30 representatives of residential communities, the platform aimed to discuss the launch of an "Appeal to create an organisation bringing together the homeowners of the city of Beijing." (28) Following this first step, official actions were taken to request the authorisation and registration of the organisation. Having been informed by an official from the Social Organisation Management Bureau of the Ministry of Civil Affairs that this request first needed to be approved by the Beijing City Construction Bureau, the homeowners approached the latter body in August 2006 with a "request for instructions" (qingshi 请示) signed by more than 50 homeowners' committees in Beijing. ${ }^{(29)}$ Several points can be underlined concerning this appeal and the request for instructions. Firstly, the two documents bring to mind the social problems created by housing reform, because although the request evokes the "discordant sounds" within residential communities in a neutral fashion, the appeal mentions "disputes" (jiufen) concerning the management of homes, and owners being "orphans and without assistance" in the face of all kinds of conflicts, in particular when up against "powerful property management companies." The need to create a federation of homeowners' committees is closely linked to these difficulties and conflicts, but the request for instructions is careful to base its legitimacy on official rhetoric concerning the construction of a "harmonious society" (hexie shehui). ${ }^{(30)}$

Secondly, the request for instructions and the appeal clarify the role and the functions that this new organisation could have: by promoting laws and regulations, and monitoring and coordinating the work of the homeowners' committees, the latter groups would be enabled to operate "in a more ordered, more standardised, and more realistic manner." While the appeal addressed to homeowners underlines that this new "social organisation" (shehui tuanti zuzhi) would allow Beijing's homeowners to have a "family" (yi ge "jia"), the request for instructions emphasises its role as a "gateway" (qiaoliang) and "link" (niudai) between the Party and government on the

24. Certain presidents of homeowners' committees had attempted, unsuccessfully and on a number of occasions, to obtain a list of the various homeowners' committees in Beijing from the local authorities. This request was granted without hesitation to the bank that organised the event.

25. See Liu Yuewen, Shehui de shanbian: yi B shi yi ge yezhu lianhe zuzhi weili, op. cit., pp. 44-46.

26. For the purpose of anonymity, we have chosen these names which reflect the way these different leaders are called within the movement: Lao meaning "old" and Xiao meaning "young," reflecting the difference in age between them.

27. Liu Yuewen, "You gushi de ren: siwei zhaoji ren de shengming licheng" (People with stories: The journeys through life of the four founders), Shehui de shanbian: yi B shi yi ge yezhu lianhe zuzhi weili, op. cit., pp. 32-40.

28. "Guanyu chengli Beijing shi yezhu lianhe zuzhi de changyi shu" (Appeal to create an organisation bringing together the homeowners of the city of Beijing), June 2006.

29. "Guanyu chengli 'Beijing shi yezhu weiyuanhui xiehui' de qingshi" (Request for instructions concerning the creation of a "Federation of the homeowners' committees in the city of Beijing"), 25 August 2006.

30. "The Central Committee of the Party has stated the objective of constructing a harmonious socialist society; the xiaoqu are the foundation of society, being the important link in the construction and management of society; they are also a major factor in the construction of the harmonious society." 
one hand, and the homeowners in the xiaoqu on the other. Thirdly, the two texts openly propose calling this new organisation the "Federation of the homeowners' committees in the city of Beijing." On the advice of a lawyer, this application was presented in the name of a "committee applying for authorisation to create a federation of homeowners' committees in the city of Beijing," the long form of yeshenwei, a precaution taken to avoid being seen as an "illegal organisation" (feifa zuzhi).

In December 2006, after this application had been under consideration for several months, the yeshenwei received a response from the City Construction Bureau of Beijing which, despite not approving the creation of such a federation, did not completely reject the application, either, thus allowing the homeowners engaged in this process a space for action, (31) as described by Xiao C. in the following interview extract:

Xiao C.:The reason we thought of creating this federation of homeowners' committees was because we hoped to build a right of association (jieshequan 结社权) that would put civil society into practice. Why to this day do we still call ourselves the "application committee" (shenban weiyuanhui)? [...] Because they have never given us authorisation (pizhun). [...] They have always said that they are considering (yanjiu) [the application], that they are considering it positively; that has been the official response so far. They have now been considering it for several years, and I think they will carry on considering it for more years to come.

Author. So they have not turned it down?

Xiao C.: No. That means that this organisation can exist, and can carry out actions as the "committee applying for a federation of homeowners' committees." (32)

The "application committee" or yeshenwei is the outcome of a need to bring together the actors engaged in the defence of the rights of homeowners, and the result of strategic discussions between several leaders of Beijing homeowners' committees. Like its counterpart in Guangzhou, although it did not obtain official authorisation in 2006, neither was it officially rejected; therefore the non-illegality of this "committee" would allow it to organise certain actions, one of the first of which was the launch of the citizen petition at the start of 2007. ${ }^{(33)}$

\section{A citizen petition to make the voice of homeowners heard}

At the end of 2006, the drawing up of the Property Law (Wuquan fa) attracted national and international attention. Since the introduction of the policy of reform and opening, although China has been turning increasingly towards a market economy, gradually authorising the privatisation of possessions, the adoption of this symbolic law has given rise to an intense ideological debate between two basically opposing visions, one taking a liberal viewpoint that considers the law to be too far to the left, preventing a fullscale shift to a market economy, and the other taking the reverse view that this law is too far to the right and damages the foundations of the one-party state. Moreover, since this law affects the interests of different social groups, its drafting attracted a great deal of interest and scrutiny from homeowners:

What we observed was that after a series of revisions, the final drafts of the Property Law became steadily worse, in particular the section concerning Article 6. They protected the rights of homeowners less and less. For example, at the outset, [...], everything that was inside the home was considered to belong to you, and everything that was outside was considered to be shared property. Yet [...], after a whole series of revisions, the only things that continued to be considered communal space [belonging to all the homeowners] were the roads and the green spaces. They took it much too far. ${ }^{(34)}$

As far as the interests of homeowners were concerned, faced with an evident loss of ground, which was influenced by certain groups that were able through the Chinese federation of property developers and their personal connections, to advance their own interests, the members of the yeshenwei decided to publish an "open letter" (gongkai xin) calling for the revision of Article 6 of the law concerning private homeownership and the organisations representing homeowners in residential spaces. As Xiao C. explains, this initiative came about in part owing to the advice of a professor at Beijing University, who was, at the time, a fierce opponent of the law and who had himself used this mode of action to influence the process of drafting the law. However, unlike the academic, whose letter was the expression of a stance taken by certain elites and had been signed by several people of influence in the intellectual and political debate, the open letter from the homeowners was aimed at achieving mass mobilisation, bringing together all the homeowners and citizens of China who were affected by this project.

Having chosen the principle of an open letter, which revisions should it request and how should this action be positioned in the highly politicised context in which the law was to be adopted? Xiao C., who was central to this collective action, emphasises first and foremost the importance of not entering into the ideological debate surrounding the law:

When we explained this action, we said that we would not tackle other aspects of the property law, because it was very sensitive (mingan). As far as the Centre was concerned, things were very tense, because this time the Property Law would necessarily need to be adopted by the National People's Congress. [...] This is why we stated that we would only address the sixth article of the Law, and would not comment on any other aspects of it. ${ }^{(35)}$

Therefore, the requests for revision were limited to Article 6 of the law, approaching it from several different angles. Firstly, in terms of the question of ownership of the communal spaces of residences, the homeowners involved demanded that all of these communal areas and spaces should belong to the homeowners. Added to this highly economic concern was a request concerning the legal status of the general assembly of homeowners

31. Letter of response from the City Construction Bureau of Beijing, 22 December 2006, internal document.

32. Interview with Xiao C., conducted in Chinese, 16 September 2010, Beijing.

33. These spaces for action are also used by other social organisations such as NCOs, which are not officially registered. For more on this subject, see Guosheng Deng, "The Hidden Rules Governing China's Unregistered NGOs: Management and Consequences," The China Review, Vol. 10, No. 1, spring 2010, pp. 183-206.

34. Interview with Xiao C. conducted in Chinese by the author with another student from the research team in Beijing on 24 September 2010. The issue of communal spaces in residences and knowing who they belong to (to all the homeowners or to the property developer) is fundamental in the eyes of the homeowners: indeed, apart from the roads and green spaces, the car parks, shops and businesses, conference centres, etc., are all important economic concerns.

35. Idem. 
and homeowners' committees. Finally, a third point called for a reduction in the number of votes needed to have decisions taken by the general assembly of homeowners adopted:

[...] It was stated that the vote of the general assembly of homeowners required two thirds of the votes cast to be in favour. I argued that this was the highest threshold in the world [...]. The vote of the general assembly of homeowners concerning [the choice] of management company also needed to win two thirds of the votes of all the homeowners. This made it very difficult for us to implement actions of this kind. [...] If you cannot find the homeowner, you will not get his vote. The accomplices of the property developers also live in the residence. At the time, I therefore wrote an article online that said that only $47 \%$ of Americans had voted in the American presidential elections, and that the elected candidate had attracted less than half of those votes. Yet that did not destabilise the country. It has always been a powerful country, hasn't it? [...] For this reason, we demanded that the required number of votes cast to validate the vote should be $50 \%$, and that of those votes, the majority should be adopted as the decision of the general assembly of homeowners. (36)

After the drafting of this open letter, the challenge faced by homeowners was that of raising awareness nationally, and of gathering as many signatures as possible in order to attract the attention of the senior leaders of the state and the Party. Preparatory meetings were organised from the end of 2006, and on 21 January 2007, the first New Year's party for Beijing homeowners' committees was held, attended by more than 400 people representing approximately 100 residences, as well as some 30 media companies. The principles behind the action and the contents of the open letter were revealed at this event. A website was also set up especially for the movement, but it was closed by the police after a few days; therefore, the committees had to mobilise their own networks in order to collect signatures, organising "mobilisation meetings" in residences in Beijing as well as Guangzhou, Shanghai, Shenzhen, and many other cities.

More than 180,000 people signed the open letter; ${ }^{(37)}$ its writers had not imagined it would meet with such a reaction, particularly in view of the problems encountered during the mobilisation process. Despite the initial success enjoyed by this open letter, could this high level of mass mobilisation really transform the drafting of the law to incorporate the demands for revision that it expressed? From this point of view, the homeowners won a partial victory. Having submitted the open letter, the homeowners received no official response. However, the final version of the law adopted during a session of the National People's Congress, and public comments made by certain officials, appear to indicate that the voice of the homeowners had been taken into consideration, to an extent.

Nobody gave us an official response, but [...] after the end of the session of the National People's Congress, [...] a vice-president of the working committee of the Congress gave a press conference $[. .$.$] in$ which it was obvious that he was giving [us] some answers. [...] Obviously, he could not give us an official answer to our open letter and its 180,000 signatories; that would have been quite impossible (laughs), but we were nevertheless pleased [that our letter] had played a role of sorts. As far as homeowners' rights are concerned, although not all of the points were accepted, it was still a lot better than it had been before, in the seventh draft of the law. ${ }^{(38)}$

Without going into the detail of the revision of the law, there was firstly a partial retreat concerning the question of communal spaces; secondly, although the general assembly of homeowners did not earn legal recognition as a "legal person" (faren), the newly recognised possibility that this institution representing the interests of homeowners could be taken to court opened up a first breach; and, finally, the number of votes that needed to be cast in order to approve a decision of the general assembly of homeowners was lowered to $50 \%$.

As a seminal event only a few months after the creation of the yeshenwei, this collective mobilisation and the success it enjoyed reflected a number of factors. Firstly, if the open letter met with huge popular approval, this was partly a reaction to the overly visible intervention of certain interest groups, in particular property developers, in the process of drafting the law, and was also the result of the mobilisation techniques developed by the yeshenwei and more generally by the network of homeowners engaged in the movement to defend their rights. Secondly, in order to influence the process of drawing up the law, the organisers of the movement combined the mode of action of the open letter with other forms of intervention (for example making informal contact with members of the $\mathrm{Na}$ tional People's Congress and seeking official support within the field of power). Their claims were restricted to technical questions, mainly of an economic nature. As underlined by Xiao C., placing emphasis on the defence of economic interests formed a "shell" protecting both the organisation and the movement:

[As a homeowner], I have a right to decide (juece quan) on how shared property or communal spaces are used. I also have a right to decide on (juece quan), carry out (zhixing quan), and participate in (canyu quan) the management of the residential community in which I live on a daily basis. All these rights are economic rights (jingji quan). Therefore, it does not really matter what we actually think, because we can fully assert that our claims are economic claims. But in reality, although this work cannot really be described as political, it does at least have a social dimension, as it does play a role in the promotion of social progress. We therefore have a very effective shell (waike 外壳), by which I mean that the whole defence of our rights is a shell [promoting] economic rights. Portrayed in this way, it [...] therefore appears to be fairly moderate in this society. ${ }^{(39)}$

This "shell" that protects the movement-organisation by giving it a "moderate" and "rational" appearance nevertheless helps promote certain modes of collective action, such as the open letter, which are resources for future mobilisations and help redefine relations between the state and society:

There is also an aspect that could be seen as progress in the journey towards the rule of law. We are able to do certain things, and if we were able

36. Interview with Xiao C

37. Idem. Some signatures were gathered collectively, the official stamp of the homeowners' committee of certain residences representing all of the homeowners in question. Although the number of individual signatures actually collected is certainly lower, the symbolic extent of this collective mobilisation and the high number of residences and homeowners committed to this action cannot be contested.

38. Idem.

39. Interview with Xiao C., conducted in Chinese, 16 September 2010, Beijing. 
to do this once, we can do it again, can't we? To start with, it has been possible to use this method, which would have been unthinkable in the past; you might have been arrested. This method makes it possible to better protect the rights of homeowners. But I think it plays a more important role in the background, insofar as citizens can use this legal method as a means of participation, and can actually influence state policies. ${ }^{(40)}$

\section{Training classes for homeowners and official discussions with the Construction Bureau}

The ground won by the yeshenwei has given rise to other types of action, which while less prominent still display the direction taken by this movement-organisation and some of its strategies. Indeed, bringing the various homeowners of the city together around shared objectives means sharing and discussing practices within the homeowners' committees, and identifying certain problems and their concrete solutions. Therefore, in 2009, "training classes" (peixun ban) for homeowners were organised at Renmin University at the initiative of the yeshenwei, among others. ${ }^{(41)}$ In the spirit of the organisers, using as a metaphor the history of the Party and the new China, it was now a case of moving from the "revolutionary phase" (geming jieduan), which saw the first movements to defend homeowners' rights in Beijing, to a "construction phase" (jianshe jieduan), the main aim of which was to produce and transmit "specialised knowledge" (zhuanye zhishi), to share experiences gathered from the point of view not only of collective protest actions but also from managing residences and the operation of bodies representing homeowners (committees and general assemblies). Rather than focusing only on "objective," unchanging, and accepted knowledge, these classes therefore involve expressing and discussing knowledge marked with uncertainty and open to debate, experiences and practices that had sometimes succeeded and on occasion failed, as well as judgements on situations involving different actors, including representatives of the public authorities.

The atmosphere in the classes is often animated, particularly when "opponents" of the movement are invited to speak; for example, one representative of the management companies who came to shed light on the facilities of residences (electricity and hot water) was subjected to several hours of repeated questioning by the homeowners in attendance. The main concern of the participants was: "Are the fees paid to the company that manages my residence reasonable (heli)?" (42)

Although the main focus of participants concerns subjects pertaining to their economic interests, other questions are also broached, including relations with residents' committees and the local authorities. For example, the session held on 27 December 2009 was given over to relations between the homeowners' committee and the residents' committee in new commodity housing. Taking a real-life case as the starting point - the refusal of a residents' committee to approve the organisation of an election to renew the homeowners' committee of the residence - the discussion concerned the respective powers of these representative bodies in residential communities. In the spotlight was the interpretation of "Document No. 54," an "internal administrative document concerning the orientation of work" (xingzheng jigou neibu gongzuo zhidaoxing wenjian), which assigns residents' committees the mission of "monitoring" (jiandu) and "guiding" (zhidao) the elections of homeowners' committees. In practice, such assignations are often used to prevent committees from being created or renewed.
Xiao R., who chaired the session, and Lao $S$., the main speaker, who is known in Beijing for the active role he played in his residence in Chaoyang District, and was also an independent candidate in the elections of the District People's Congress in Beijing, both stress the limitations of this document: in the hierarchy of laws and regulations, this internal document does not have the force of law; what is more, "guiding" is not synonymous with "commanding." The view of Lao $\mathrm{S}$. is that "the leaders need to be transformed" (yao gaibian lingdao), or in other words, their behaviour needs to be modified. However, this would require a "change of mentality" (huan yi zhong siwei luoji), for the legitimacy of the homeowners' committee comes from the work it does for the community of homeowners, not from an official stamp. ${ }^{(43)}$ Xiao R. feels that "if the residents' committee intervenes [in the business of homeowners], there should be no fear of blaming the government. A particularity of the middle class is that it is afraid of disorder." He goes on to advise homeowners to use the same united front strategy (tongyi zhanxian) as Mao Zedong: "It is difficult to win the support of homeowners, but it is possible to obtain the minimum level participation. In order to defend rights, you have to give homeowners a few advantages." (44)

Taking power in the residents' committees by participating in the elections is another strategy highlighted in the training classes, even though in practice such an approach is fraught with many difficulties. Applying the law to denounce certain official behaviours while using the power of numbers to advance the cause of homeowners are two aspects of a common strategy whose aim is to strengthen the power of the bodies that represent homeowners. Despite the many external pressures, in particular from the residents' committee and the Sub-district Office, the central problem that crops up during the training sessions is that of the internal relations between homeowners. In other words, the difficulty lies in coming to a decision together and having decisions approved, in particular when they bring economic interests into the equation. Which shared norms and rules should be used to form a homeowners' committee and make it operate?

From this point of view, the various contributors in the training classes all stress certain "principles" (yuanze) that must guide both the process of forming a homeowners' committee (elections) ${ }^{(45)}$ and its day-to-day operation and the actions it organises in order to ensure its legitimacy (hefaxing). Putting in place "procedural rules" and "management rules," "the separation of powers" and the "protection of minorities" are essential principles to ensure a committee functions properly, and represent "the constitution of the xiaoqu" (xiaoqu de xianfa). ${ }^{(46)}$ The training sessions are not merely an exercise in chanting abstract principles; they introduce "institutional innovations" (zhidu chuangxin) that make it possible to put these rules into practice. For example, Lao S., committee ex-president in his residence in

40. Interview with Xiao C. conducted in Chinese by the author with another student from the research team in Beijing on 24 September 2010.

41. These classes were open to anybody interested in the question of the governance of residential communities: members of homeowners' committees, homeowners, volunteers in neighbourhood communities, students, etc.

42. Field notes, 30 October 2009.

43. Field notes, 27 December 2009.

44. Field notes, 22 November 2009.

45. During the session of 30 August 2009 , Xiao R. set out the principles by which elections must be organised: the right to vote, equality of the right to vote, the right to form a list of candidates, direct suffrage, secret ballot, public announcement of the results, etc. This statement of the rules implicitly emphasises the many difficulties encountered in practice: intrusion by the residents' committee or Street Bureau, disputes between homeowners when the results are announced, theft of the ballot box, etc.

46. Session of 30 August 2009 , field notes 
Chaoyang District, bluntly states the main problem facing homeowners' committees: "How can dictatorship and corruption be avoided?" He sets out the rules he put in place concerning the use of the official stamp of the committee and the recruitment of a secretary in order to avoid any abuse of power by the committee president. ${ }^{(47)}$

However, promoting "grassroots democracy" (jiceng minzhu) through "citizen education" (gongmin jiaoyu) is not without obstacles. During the sessions, many voices questioned or even challenged the validity of the actions and principles put forward by the yeshenwei. Older homeowners were particularly doubtful about the strategy that was being followed: "You are too idealistic," "These principles cannot be achieved," "The yeshenwei is not a legal organisation," "All that you have undertaken to do over recent years is worth nothing..." were sentences often heard during the training classes. Some advised the yeshenwei to "cooperate with the government," even emphasising that "the Party should be left to manage property and homeowners," while others criticised the inefficacy of the rational and legalistic strategy adopted, compared to activities of a more disruptive nature (naoshi). ${ }^{(48)}$ The vocabulary of "citizenship" (gongminquan) used by certain leaders is also challenged owing to its politically "sensitive" (mingan) nature: talking of "civil society" (gongmin shehui) and "citizen awareness" (gongmin yishi) is thought to scare the laobaixing and create risks for the movementorganisation and its participants. These differing reactions reveal the fragility of agreements built up between the participants in the movement to defend homeowners, and the doubts expressed with regard to the strategy adopted and principles of action put forward by certain leaders. At a more fundamental level, the commitment of one section of the elite of the movement to the "construction of civil society," or in other words, greater independence of society from the state, finds itself scrutinised in the name of the effectiveness of the actions undertaken.

The training classes display both the importance of the law in the eyes of the leaders of the movement and the ability, developed during the course of the collective mobilisations, to use the law as a "weapon" of defence against representatives of the state and the market; they also show the limitations of this strategy and the need to develop the legitimacy of these new representative bodies according to shared and recognised norms and institutional arrangements. Can this "specialised knowledge" and the "institutional innovations" transmitted during these classes be recognised by State and Party representatives? Can cooperation with the government, as requested by one section of the homeowners, be envisaged, and is it even to be desired?

Although when it was first created, the yeshenwei was not considered to be an illegal organisation, it nevertheless attracted a certain amount of suspicion from state and Party representatives. ${ }^{(49)}$ Following a period of "tacit tolerance" (moxu 默许), in spring 2010, an official invitation by the Construction Bureau of Beijing to the members of the yeshenwei to take part in the process of producing a new local regulation concerning homeowner committees and general assemblies indicated a degree of "recognition" (renke 认可) of the organisation. To the surprise of its members, the yeshenwei, which was considered to be the homeowners' representative, was asked to produce its "version" of the regulation, which was to be compared to that of the Construction Bureau of Beijing. This invitation gave rise to a number of internal discussion meetings during which the general strategies to be adopted were debated - should "compromise" be the watchword from the outset or, conversely, was it wiser to adopt a firm position aiming to impose a maximum number of constraints on the government? ${ }^{(50)}$ - in addition to many technical details on the proposed rules. ${ }^{(51)}$
The meeting and official discussions were then followed by a new meeting between the homeowners. In his report, Xiao R. expresses his surprise that not only was the tone of the discussion cordial (the representatives of the Construction Bureau even used the expression "zanmen 咱们" to stress the idea that the new regulation was to be a shared co-production), but more surprising still, roles previously assigned to the residents' committees had disappeared from the Construction Bureau's version! Some "institutional innovations" previously introduced and put into practice in certain residences, such as the "Homeowners' representative assembly" (yezhu daibiao dahui), an intermediate level between the homeowners' general assembly and the homeowners' committee, also appeared in the text, giving these innovations a legal value. However, vigilance did remain: "Don't consider them to be too generous," commented one activist, referring in particular to certain proposals such as the creation of a "pool of experts" that would become responsible for monitoring the creation of the committees. "We don't need experts; what we need is citizens"; "The government sells services, and washes its hands of its responsibility, yet this gang of lawyers is worse still." (52)

Although this official meeting was seen as recognition of the legitimacy of the yeshenwei as representing the interests of homeowners, the experiment was to be short-lived; as early as August, the departure of the official who had been the main contact of the homeowners, and his replacement with a new cadre, resulted in this dialogue being broken off. Therefore, although the new regulation introduced some of the "citizen" proposals of the yeshenwei, it did not achieve the aims that had been hoped for. This conclusion shows the significant limitations to these forms of dialogue with official state representatives, the manipulation of the participation of representatives of society, and the extreme vulnerability of this non-legal and non-illegal association to any change in the political context. ${ }^{(53)}$

\section{Conclusion}

As I have emphasised over the course of this article, the emergence of the yeshenwei as a "political collectivity" (54) takes place at the point of convergence of a number of phenomena: a reform of the status of home ownership in urban China, an "urban modernisation" campaign that incorporates var-

47. Session of 26 July 2009 , field notes.

48. The question of the "legality" of the collective actions gave rise to a heated discussion during the session of 30 August 2009. Indeed, Xiao R. stressed the dangers posed by actions that could be judged to be "illegal" to the organisation and its leaders. He observed that demonstrating was illegal outside the residence, but not inside. He was interrupted by a homeowner who insisted that street demonstrations were an effective way of making one's voice heard and forcing the government to intervene in order to solve conflicts in residences. One homeowner then defended the idea that it was possible to demonstrate in the street but that the homeowners' committee should not organise this action. The president of one homeowners' committee then explained how his residence proceeded in order to bring pressure to bear on the government without doing so illegally: they went to the local police station to legally register an application to hold a demonstration. Although this application was obviously refused, it did result in the authorities immediately reacting to resolve the conflict.

49. Interview with an official responsible for housing questions in the district of Haidian, December 2009, Tsinghua University.

50. Zhou Mojun, "Debating the State in Private Housing Neighbourhood: The Many Meanings of Homeowners' Associations in Urban Shanghai," article sent by the author. Jean-Louis Rocca, "Homeowners' movements: Narratives on the political behaviours of the middle class," in Minglu Chen and David S.G. Goodman, Middle Class China: Identity and Behaviour, Cheltenham, Edward Elgar, 2013, pp. 110-134.

51. Meeting of 12 July 2010 , field notes.

52. Meeting of 18 July 2010 , field notes.

53. Ching Kwan Lee and Yonghong Zhang: "The Power of Instability: Unraveling the Microfoundations of Bargained Authoritarianism in China," art. cit.

54. Isabelle Thireau, "Introduction," De Proche en proche (Face-to-face), op. cit. 
ious strategies (transformation of the forms of social control and recognition of new bodies representing inhabitants), and the coming together of actors who, using their diverse forms of capital and legitimacy, are establishing a sense of collective mobilisation around a common cause: the defence of the rights of homeowners.

Studying the process of forming and developing this organisation from founding events ${ }^{(55)}$ that characterise its history makes it possible to grasp how these mobilised homeowners have been able to construct a space for action on the fringes of legality and how this space for action has served as a place not only where common claims have been formulated but also where norms and practices of operation of homeowner associations have been promoted. Observing the actions of this movement-organisation (for example the open letter of 2007 or the training classes of 2009) encourages one to take seriously both the actual economic claims that are drawn up and the principles and repertoires of action that are developed. Far from being in opposition to each other, it is actually the conjunction of economic claims on the one hand and "citizen" practices on the other that explains the success of certain collective mobilisations. By moving away from the area of concrete claims, the elite of the homeowners' movement is running the risk of cutting itself off from its social base and increasing the number of political threats that hang over the organisation. Conversely, without the establishment of shared rules based on the principles of democracy and equality, and without learning about the constraints that hinder collective action and condition its legitimacy, the new representative bodies constituted by homeowners' committees run the risk of "dictatorship" and "corruption," or are at the very least unable to build up the legitimacy and authority they need in order to operate. ${ }^{(56)}$

Furthermore, potential disputes within homeowners' committees and disputes between residents concerning the principles according to which their representative bodies should operate weigh heavily on relations between these new organisations and state and Party representatives. From this point of view, we have been able to observe how the yeshenwei, owing to its ori- gins and the characteristics of its founding members, as well as the various collective actions it has carried out, combines contestation with conciliation to make the voice of its homeowners heard. As certain members of the yeshenwei like to mention during their meetings, often jokingly, they are "acting in favour of the Party" (wei dang zuo shi'er): they are calling on the one-party state in the name of its role as arbiter of interests between different social groups, denouncing the hold certain privileged groups (tequan shehui tuanti) such as property developers have over public policy and local governments. They are also calling on the one-party state in the name of its role as guarantor of the law and its application, with "law" being seen in this context less as a basis of legitimacy than as a battlefield on which to not only influence the concrete content of certain laws and affect the process by which certain regulations are drawn up, but also, at a more fundamental level, to restrict the area of intervention and limit the powers of the one-party state (in particular its local representatives) and to promote the development of a civil society.

Although the aborted discussions with the Construction Bureau of Beijing in 2010, and the more recent shelving of yeshenwei activities as the $18^{\text {th }}$ Congress approached, highlight the vulnerability of this movement-organisation and the heavy constraints that weigh on the promotion of this "rational" and "legalistic" strategy to unite common interests and defend rights, the "citizen education" (gongmin jiaoyu) movement that is underway and the mobilisation methods developed suggest that this story has some way to go, and that new common causes (concerning the tax system, for example) could arise and make use of the resources and methods developed by this movement-organisation.

\section{Translated by Will Thornely.}

\author{
Aurore Merle is a researcher at the CEFC and Lecturer at the \\ Sociology Department of Tsinghua University. \\ CEFC, 20/F Wanchai Central Building, 89 Lockhart Road, Wanchai, \\ Hong Kong (amerle@cefc.com.hk).
}

55. Sun Liping, "'Guocheng - shijian fenxi' yu dangdai Zhongguo guojia - nongmin guanxi de shijian xingtai" ("Process-event analysis" and the relationship in practice between the state and farmers in contemporary China), Qinghua shehuixue pinglun, No. 1, May 2000.

56. Yongshun Cai and Zhiming Sheng shed light on this combination of requests from the mixed motivations of the leaders: "Homeowners' Activism in Beijing: Leaders with Mixed Motivations," The China Quarterly, Vol. 215, September 2013, pp. 513-532. 